\title{
On source criticism in world history
}

Janken Myrdal

As noted by several authors in this volume, the lack of discussion about source criticism in world history is a serious problem. It is, in fact, a threat to the credibility of this branch of history. When world history forms the basis for grand theory, with implications for how we deal with current problems in the world, source criticism will be of particular importance. We must develop methods of evaluating overarching surveys and syntheses. Preferably, they should be testable in a Popperian way: it should be possible to refute them (Popper I965: 220, 232).

One way to write world history is as a general synthesis valid for a large part of the world and involving key elements of historical change: macrohistory. Such surveys are often constructed as narratives and combine condensed descriptions of processes with selected facts and extensively described examples. Indicators are combined to sustain a grand theory.

In testing such a general synthesis I will focus on a specific kind of indicator: the measurable. I include not only numbers in tables, but also presentations in maps and graphs. The reason I focus on this kind of indicator is that the results can be corroborated or, if necessary, rejected. Thus they form a kind of touchstone for grand theory in world history. If a grand theory is contradicted by important measurable indicators, this will affect the plausibility of the theory.

This may seem like a plea for quantitative methods, and to a certain extent, this is correct, but any such quantification requires a detailed qualitative analysis and description. Measurable indicators 
also form only a minor part of all empirical evidence that is combined to corroborate grand theory, and critical methods must be developed to evaluate how other indicators are handled and combined.

Another way to construct world history is to combine examples, typically regional studies, into comparative history, which also can form the basis for grand theory. There is some, but not sufficient, methodological discussion about this kind of world history. Issues related to context, depth, and consistency have been raised (Adas 2012). Since including elaborate studies is a goal, multidisciplinary area studies become a base for such comparisons (Manning 2003: 86-9I, I 46-I62, 22 I; Manning 20 I I: I I2). A problem treated by Eva Myrdal in this volume is the different quality and intensity in research regarding the areas compared. Another important problem is that the examples often are presented in ways that are not comparable. This is treated by Arne Jarrick and Maria Wallenberg Bondeson in this volume.

A further major problem in comparative history, seldom discussed, is representativeness. If a comparison between cases forms the basis for a synthesis, a bias in the choice of examples may weaken the conclusions. Often it seems that cases are chosen from well-explored regions, or from regions the participants in the volume, or the project, themselves know well. The most common method of handling this problem is to provide a context. If, for instance, a region in the Philippines is chosen, then we also get an overview of such things as early colonial history, contacts with China, and so on. This implies that macrohistory is important also for comparative history - and certainly both these ways of writing world history are integrated and sometimes merging into each other.

Below I will treat some problems with measurable indicators for world history. I start with surveys based on subjective measurements, arguing that reporting the basis for measurement is always preferable. Then I move on to surveys based on out-dated measures. A third step is to accept that these indicators only show one aspect, and alternative measurements will make different aspects appear. Next I discuss how strict selection can create a better basis for interpretations, which also relates to the question of the categories utilized. The last part is devoted to a test of a grand theory, where I use the proposed methods. I focus on a part of the theory, or more specifically on a prerequisite for the theory. 
My examples are from different investigations I have made, most of them instigated by a frustration I felt facing the lack of a methodological discussion in this branch of history. All the indicators I discuss are related to statehood and ideological-political processes, as it seemed to be an advantage if they were roughly in the same field and in some way related to each other. In a parallel project I, together with Mats Widgren and others, am doing a survey of the world history of agriculture, which forms a background to my work with source-critical problems. I do not touch upon that project in this text, but see Widgren's contribution to this volume. My purpose is only to discuss methodological questions, and if results concerning political world history are presented, they are a side effect. Before I start to discuss how source criticism can be developed, something must be said about the sources.

\section{Sources}

Literature is the main source that world historians work with, a fact that is sometimes mentioned in passing but seldom discussed at length (e.g. Conrad 2013: 89). To put it a bit drastically: other scholars should be treated as sources to be scrutinized in a sourcecritical way. I will refer to three layers: besides primary and secondary sources I also discuss tertiary literature for works mainly relying on secondary literature.

Primary sources. A researcher who works with large syntheses may obviously have been using primary source material to substantiate the discussion, but this research is usually published separately. Sometimes world historians work with editions of primary sources and then are dependent on translations and secondary literature see Jarrick and Wallenberg Bondeson in this volume - and also the example about agricultural treatises below.

It can be an advantage if the author of a synthesis has researched primary source material in depth. The historian who has devoted years to archival research or the archaeologist who is experienced in fieldwork has an advantage in realizing how fragile factual evidence can be. Important syntheses can certainly be written by others than historians and archaeologists, such as sociologists, but those who have 
not worked with primary source material sometimes have difficulty in understanding the need for source criticism.

Secondary sources are interpretations of primary sources, such as archaeological excavation reports or monographs based on a specific series in archives. Any scholar working with inclusive world history can only cover a small fraction of this literature, and strict selection must be made in using secondary literature.

In a discussion about methods for comparative history as a basis for synthesis, Theda Skocpol argues that it is imperative to make occasional "targeted primary investigations" referring back to the primary sources (Skocpol I 984: 382-383). An extensive reading of original research on specific topics in secondary literature is equivalent in a general synthesis to Skocpol's principle of targeted investigations. In-depth studies can be made as a general control, but there are also specific reasons to make such controls. A scholar may find it necessary to read secondary literature when tertiary literature is not available for that region or period. Other situations forcing the scholar to be acquainted with secondary literature are when the tertiary literature presents results that are difficult to interpret or when alternatives rendered by different scholars are contradictory.

When scholarly literature is regarded as source material, the researcher is faced with a major concern, namely evaluating secondary source material. When evaluating one can be content with just identifying researchers to be trusted, as Chris Wickham once frankly stated in his grand synthesis about the early Middle Ages in Europe (Wickham 2007: 7). Sometimes one has to resort to this method, but it has risks. Skocpol has pointed out that there is danger in relying mainly on well-known scholars. Important texts may sometimes be found in the forgotten corners of research (Skocpol I984: 382-384). In this volume Mats Widgren discusses source-critical problems in secondary literature.

Tertiary sources, then, are based on secondary sources and form the foundation for much of current world history. A fundamental issue to be addressed is that older texts are less useful because of the rapidly growing amount of research on primary sources. This problem does not apply to the same extent to secondary sources, as 
a study of primary source materials may be relevant even if it was published many years ago.

Besides world history proper, several other types of tertiary sources can be used, such as national surveys, which tend to focus on political history but can also include economic history, cultural history, or more specific areas; standard works for larger regions about specific topics (e.g. Needham's series on science in China, Needham I 954-); specialized encyclopaedias (e.g. Der Neue Pauly for antiquity, Cancik \& Schneider 1996-2003); historical atlases, and statistics.

To evaluate tertiary sources, scholars use a number of simple checks as a matter of course. One is to run through the dates of publication of works included in the references. If the latest publication in the list is old then the text as a whole may be less useful. Another control, which can be done mainly by those who have worked with primary sources, is to assess sections on specific topics that one is particularly familiar with. If there are too many errors the entire text may be unreliable.

It must also be recognized that the limits of critical world history are determined by the quality of the existing literature. When working with measurements, descriptions in historical sources or in scholarly literature often have to be transformed into something measurable, be it a map or a graph. In the discussion below I will try to reveal such weaknesses also in my own investigations.

\section{Synchronoptic graphs}

The first source-critical problem I will discuss concerns how to avoid subjective measurements.

Eurocentrism is often in focus when bias and source-critical problems are discussed (see several of the chapters in Bentley 20 I I and in Northrop 20 I2). A popular kind of synthesis is synchronoptic graphs, which try to describe historical change at one glance, but they are seldom discussed or analyzed in scholarly world history.

Visualizing is an instrument used in world history. In texts about world system analysis, graphs or maps are often used to describe core and periphery or the economic systems covering large regions.

In the graphs I will discuss Eurocentrism is obvious, and therefore 
they form a good example of what subjective measurements may entail. But the problem lies not only in this bias, but also in that these graphs cannot be tested because the basis for the measurements is not indicated. The same criticism affects many of the sketches made in world systems research. I do not suggest that such sketches should not be made, but they could be supplemented by graphs or maps where the underlying dataset is reported in detail. In this volume Rikard Warlenius discusses measurements that could be developed to sustain theories about world systems.

A synchronoptical graph typically describes the rise and demise of nations and empires. Each nation's history is converted into a flow, like a stream through history. The width depends on the influence awarded to this nation. The flow runs from top to bottom, sometimes from left to right. For example, the Roman Empire begins as a small stream, grows into a mighty river and then disappears completely. The aim is to give an immediate picture of world history as a whole. Such graphs have been mass-produced, and have influenced the popular view of world history. In all these graphs, what is measured is a subjective estimate of importance, and they show a clear Eurocentric bias.

The graphs are often quite beautiful, like works of art, and are also collectibles. Daniel Rosenberg and Anthony Grafton (2010) have provided a thorough description of their historiography. In the mid-eighteenth century the first real flowchart was made by the cartographer Thomas Jeffreys in 1753; among later examples the most famous were by Joseph Priestly in 1769 and Fredrik Strass in I 804. Flowcharts became popular in the United States. Sebastian Adams published a pictorial variant in $\mathrm{I} 87 \mathrm{I}$, still sold today as a curiosity; it starts with God creating the world.

The most common flowchart during the twentieth century was the Histomap from I93 I. It was made by an amateur, John Sparks, and was on sale until the late twentieth century. According to relatives he began constructing the chart for his own amsusement, to pass the time. The success when it was published came as a surprise to him (Rosenberg \& Grafton 2010: 217-219).

Europe is dominant in the charts from the eighteenth century. Jeffrey in 1753 allots 50 per cent of the space to Europe, and Priestly in 1769 allots 57 per cent, with Asia awarded a surprisingly high 


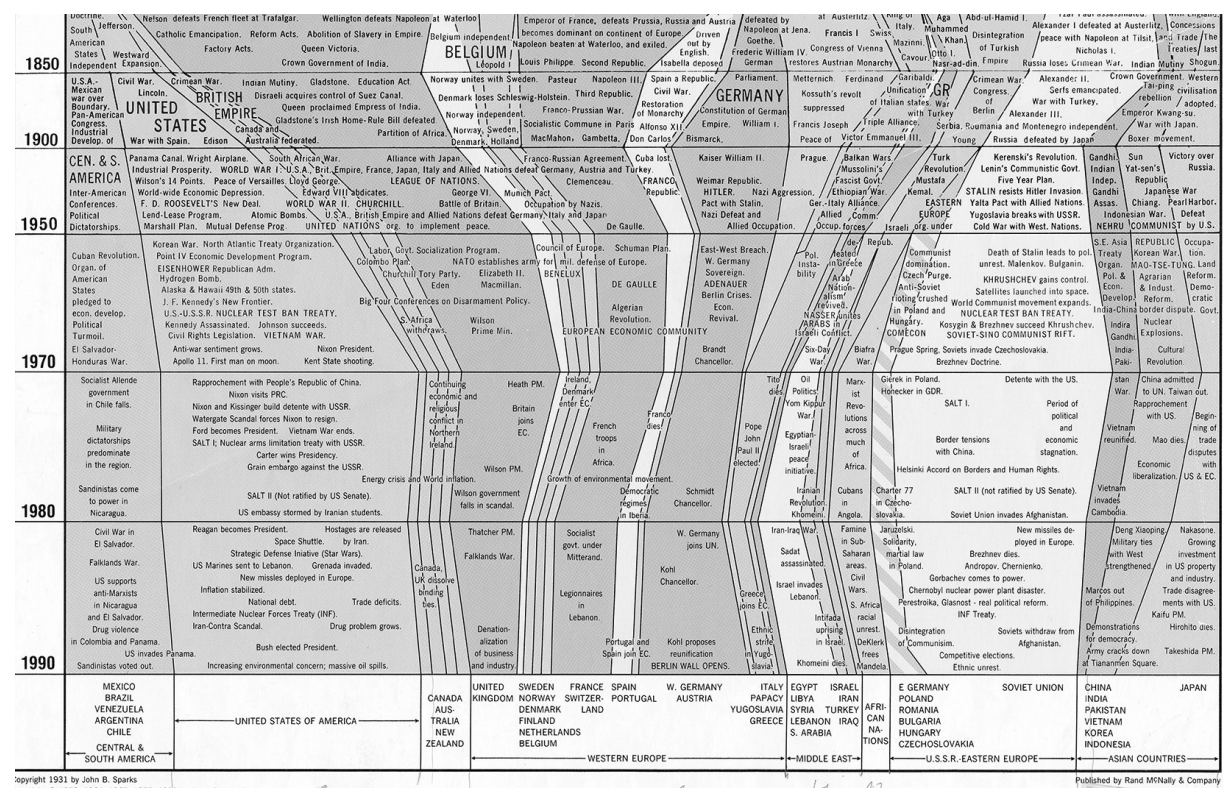

Figure I. The final part of Spark's Histomap in the I 990 version, from $c$. I600 until today. The lower half of this section covers the twentieth century, which thus has been made much longer than other centuries. The triangle to the left is the US. Immediately to the right of the US we find the British Empire, and two other large "streams" in the middle are France and Germany.

proportion, 37 per cent in Jeffrey and 27 per cent in Priestly. The German Strass from I 804 is slightly harder to estimate as the regions in the flowchart are of different sizes in different periods, but around I 800 Europe took up 75 per cent of the space.

This distortion remains today. To exemplify this Figure $2 \mathrm{a}$ and $2 \mathrm{~b}$ show how two modern graphs describe four countries: the United States, France, China and Japan. One is based on the very widespread American Histomap from I93 I (here used in its I990 edition), the other is a French graph from I99I (Fournet I99I). As expected, the American graph awards great significance to the US in the twentieth century, and both emphasize the importance of the West. Europe is awarded 4I per cent around 1900 in the American graph (in the I93 I version Europe was awarded as much as 48 per cent). In the French graph Europe covers 34 per cent. A graph that has replaced the Histomap as the most popular, the World History Timeline (20I4, produced by 
Figure 2a. A simplified sketch of the complete Histomap I990. Countries marked from left to right: USA, France, China, Japan. This graph illustrates a relative proportion (i.e. where the whole is roo per cent). Source: Sparks I 990.

Oxford Cartographers), has similarities with the French graph and gives Europe 32 per cent of the space and Asia 3 I per cent Interestingly, we find the same pattern in a Japanese graph from the I990s (Yamasaki I 999). All parts of the world are placed within strict rectangles and Europe gets about 40 per cent of the space, East Asia about 25 per cent.

These graphs reveal a marked Eurocentrism: one reason they remain influential is that scholars seldom discuss them. In fact a challenge came from Arno Peters, best known for his world map, presented in 1973, where he used a projection of the world giving a more accurate and less Eurocentric representation. The map caused intense discussion (Kuchenbuch 20I I; Oswalt 20 I 5: I 85-202). Though the map as such was not accepted by geographers, it contributed to a change in standard projections. The map actually was a sequel to Peters' earlier project, the Synchronoptische Weltgeschichte (Synchronoptic World History), first published in 1952 . This was also based on his opinion that all civilizations had

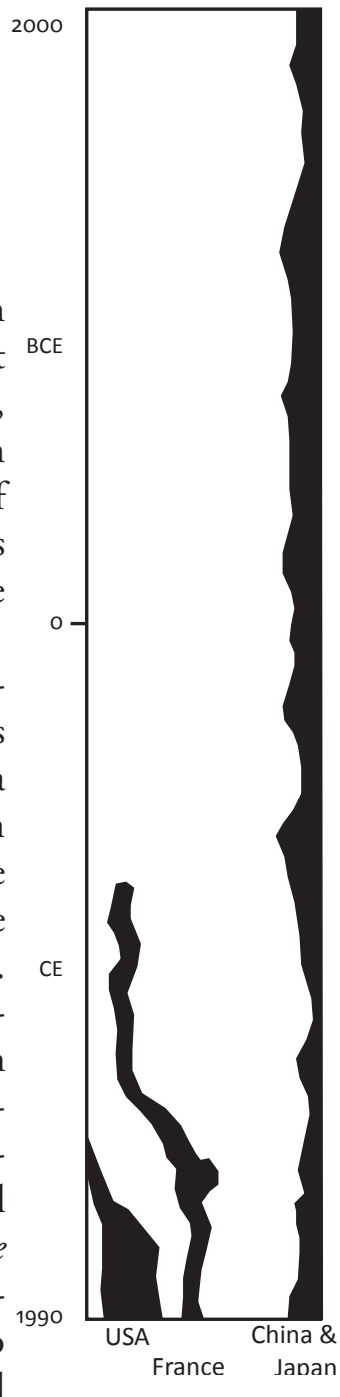
the same value, and his choice of presentation was guided by his interest in propaganda and outreach. Instead of a graph of states he had a timeline with people, political events and cultural achievements. His book was criticized by conservative historians (see Kuchenbuch 20 I I: 834-839). Today such timelines are rather common and Eurocentrism is less pronounced (e.g. Teeple 2002).

The synchronoptic graph, like all other means of presentation, 


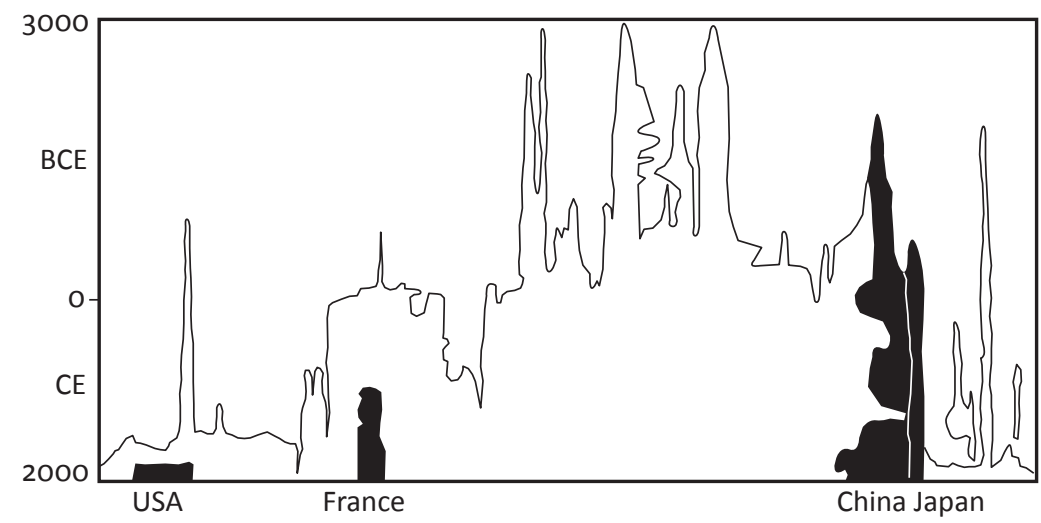

Figure $2 \mathrm{~b}$. A sketch of a French synchronoptical graph from around I 900 . This graph illustrates how states occupy an absolute proportion of the world. The French graph starts in $3000 \mathrm{BCE}$, and every century is assigned the same space. Source: Fournet I99I.

can be used as an analytical tool. To leave this kind of presentation to popular and subjective graphs is a scholarly mistake and underestimation of how powerful they are in visualizing a conception of history. Did the US really have such an influence in the world in the twentieth century as the Histomap indicates? Such a claim has to be sustained in a way that makes it possible to reject. These graphs, with their question about the influence of nations, could have been made verifiable by relating them to measurable factors such as population or military strength.

I have chosen to show how such a graph can be used to analyze a particular phenomenon. When the first larger states in Eurasia were established nearly all of them grew along a line across Eurasia from the Mediterranean to northern China. In the synchronoptical graph the measurements establish that these larger states were situated approximately along a line at a latitude of 40 degrees N. Unlike more subjective measurements this can be tested and questioned.

The dataset is a survey of the historical atlases published in the decade around 2000 (see below and Figure 3). This is a tertiary source, and my graph cannot compensate for the weaknesses in this source. One such weakness could be that the earliest states, such as the Shang dynasty in China, should be marked differently to emphasize their different character. 
The graph does not go beyond $500 \mathrm{CE}$. The Islamic caliphate and subsequent empires can no longer be portrayed as an approximate band across Eurasia. (Even in my graph states with an extension along the north-south axis, such as the Maurya Empire, will be underestimated,) The graph includes the larger early states, gradually concentrating on the empires, defined as entities united under one authority and eventually transformed into a mega-state.

Thus in the later part of the diagram states of similar size as Egypt in the earlier part are not included. Had all such states been included there would have been hardly any white space in the lower part of the diagram. It would have been difficult to read and even more difficult to construct. The main reason I have simplified the lower part of the graph so that only the largest states have been included is that a complete reporting would have added nothing essential to the interpretation about a rapid increase of larger states around 500-200 BCE.

The dotted line includes the area under the influence of these larger states from the middle of the first millennium BCE (concerning influence, see below). What is depicted is a partially irreversible process, and even if larger states were dissolved, such as in China where three states replaced the Han dynasty, the structure of the society had fundamentally changed. The graph illustrates how larger states and their influence became of major importance over most of Eurasia from the middle of the first millennium. This process started in the core area in West Asia. In the following centuries it spread, at first eastwards and then to the west. Around the beginning of our era Eurasia, in a broad band across the mega-continent, was organized under large states.

The interpretation of this graph is here mainly left aside, with questions remaining, such as how long-distance trade across Eurasia contributed to the growth of states in relation to intrinsic state-forming processes. The example is intended, rather, to show how this form of presentation would be used in a falsifiable way as a contribution to the analysis of a phenomenon in world history.

The graph is based on the newer generation of atlases discussed in the next section, and maps are of course approximations. What the graph gives is a basic outline and its exactness should not be overestimated. 


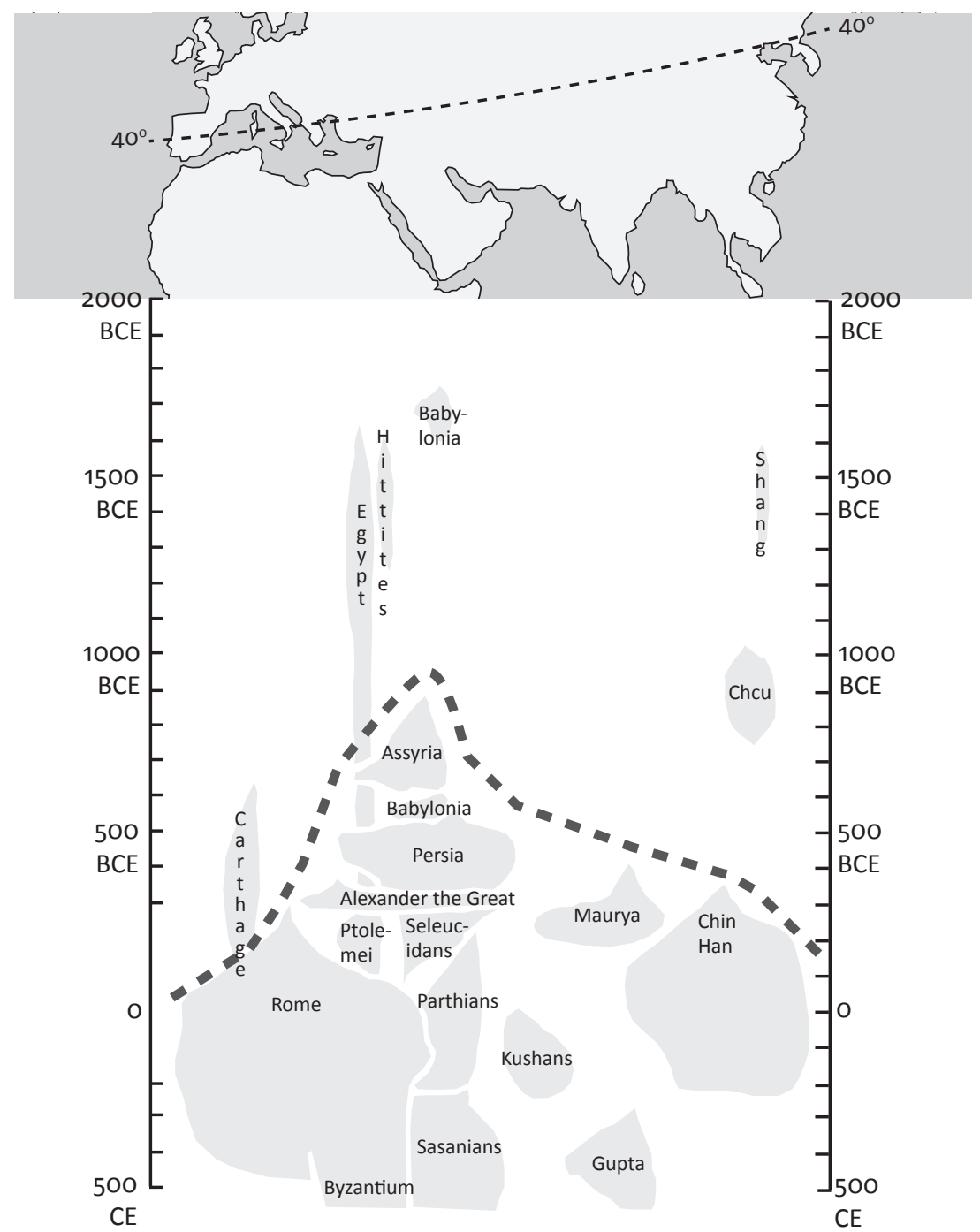

Figure 3. The major empires approximately along a line at a latitude of 40 degrees $\mathrm{N}$ across Eurasia until $500 \mathrm{CE}$.

Note: The $\mathrm{X}$ axis is the map above the diagram. Narrow protruding land areas have not been included, such as the Chinese corridor covering the trade routes into central Asia over the Taklimakan Desert. The dotted line marks the area of influence for larger states.

Source: Myrdal 2003. 


\section{Measuring empires and states}

I now turn to the source-critical problem that appears when scholars use outdated datasets. It came as a surprise to me when I realized that many world historians used a dataset based on atlases from the I 960 s and I970s, although a shift in cartographical description of world history had occurred around 2000. Thus I started to measure empires and nations in the new atlases (Myrdal 2012).

Research on large states and empires is a classical field of world history, and it is most often written descriptively. A number of well-known empires are described and then conclusions are drawn. In addition, there is a long tradition of measuring the strength of empires with quantitative data. The possibility of finding a quantitative indicator is based on two related factors. First, rulers have been interested in marking the extent of their power with monuments or in documents. Thus the approximate area of states can be followed far back in history, for some early states back to around 3000 BCE. Second, historians have traditionally been interested in political history. When historical atlases were first put together, the extent of states was the wholly predominant phenomenon to be mapped. (A very simple definition was used: a state is a political entity that controls a territory.)

These factors seemed to make it possible to measure the area of states, and this has been done for more than a hundred years. In the late I970s an Estonian scholar who had emigrated to the US, Rein Taagepera, decided to measure all the states in available atlases. His articles were, for the time, an impressive attempt. The most often-quoted graph was his diagram of the extent of the three largest states through history, that is to say, those that at a given time were the largest. He was able to prove their almost constant expansion, with some peaks on the way: I) the Roman Empire/Han dynasty, 2) the Mongol Empire, and 3) the British Empire (Taagepera I978, with the most-used graph and the summarizing article in Taagepera I 997). Taagepera bases his measurements on a number of historical atlases from the i960s and around 1970.

First it must be said that Taagepera's graphs marked a major advance, and he also meets the Popperian requirement. These graphs can be tested and - partially - rejected, as there is a problem with them. The dataset has changed. 
In the late I970s a totally new generation of historical maps appeared. This shift occurred first in the United States, but was also accepted in other Western countries. The Times atlas of world history (Barraclough 1978) was the first in this new generation, with the first edition published in 1978. The idea was to give a fair description of other countries in the world apart from Europe and North America. Then other atlases followed, and around 2000 a number of new historical atlases were produced.

The historiography of historical atlases is described in two important books by Jeremy Black (Black I997a; Black I997b). In particular he highlights the shift in the I960s and I970s and onwards from Eurocentrism. He also notes examples of historical maps used for political purposes or to enhance the author's own nation. Two historical atlases that provide an exemplary scientific apparatus and detailed references are Schwartzberg (1978) and Grosser historischer Weltatlas. Erläuterungen I-4 (I976-I996). In the latter there are essays about each map. In the former, besides long texts accompanying each map, there is also a thought-provoking review of ten different accounts of the Kush (Kushan) Empire's limits, and of nine accounts of the Mughal Empire. This is one of the best sourcecritical reviews I have read about measuring empires (Schwartzberg I978: $x x i x-x x x v)$.

These new generations of atlases were not only less Eurocentric, they were also based on new research that tended to problematize the concept of state and state control (for a discussion of archaeology, see Yoffee 2005, for history Manning 2003: 190).

A different picture emerged for the first 3,000 years. Taagepera's measurements did not even come close to those found in the new atlases. The area under the firm control of early states was much smaller in the modern cartographer's view. Another important feature is that modern cartographers sometimes work with two units of measurement: direct control and influence. This is the result of a deeper understanding of the different nature of earlier states compared with later states. In a world with large tribal areas, states often did not have a border against other states, but against tribal areas where state control was not a strict border but a gradient. If the area under direct control had been vastly overestimated in earlier atlases, the area under 
state influence often stretched beyond the area earlier considered to be under state control. We then get two curves, one much lower than the Taagepera curve and the other much higher. They approach each other in the last centuries before our current era (see Figure $4 \mathrm{a}-\mathrm{b}$ ).

In contemporary atlases there is growing awareness of this. In the atlas to Der Neue Pauly from 2007 (Wittke, Olshausen and Szydlak 2007) this principle of separating areas of control and influence is used consistently. Guy Halsall has made an interesting attempt with maps of the fall of the Western Roman Empire. With shades of white and black he shows the empire's gradual loss of control over the provinces during the fifth century (Halsall 2007: 235, 246, 275).

We also need to problematize later periods. One example is that for some large empires such as the Mongol Empire, we have to work with the two categories just mentioned. The same is valid for the British Empire in many of its colonies: firm control versus influence.

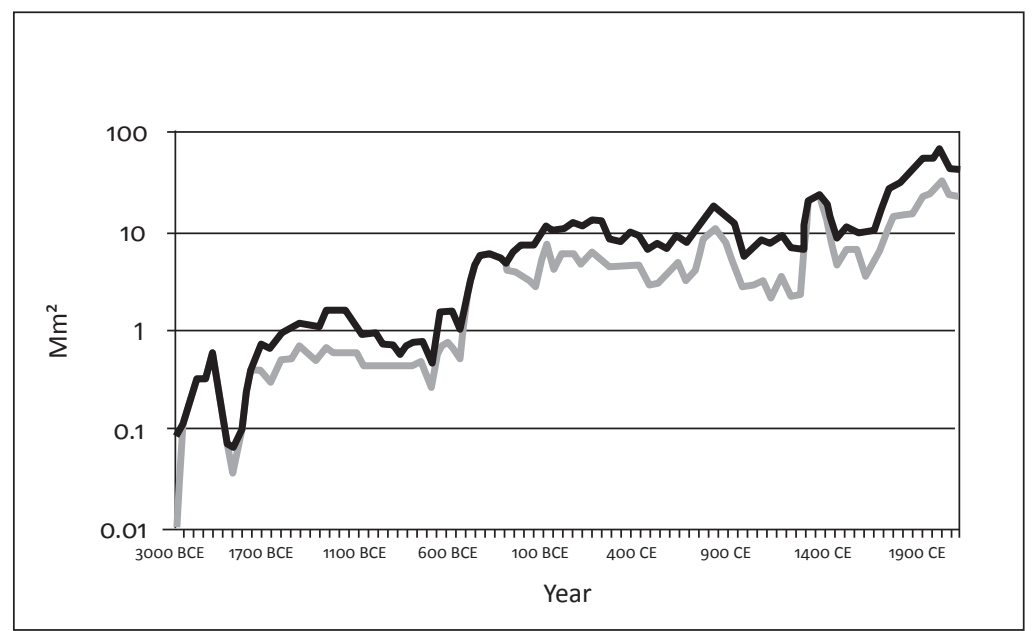

Figure 4a. Area of the largest empires-three largest empires. Taagepera's curve from I978, complemented with values for the last decades and adjusted.

Note: the largest state (lower curve) and the

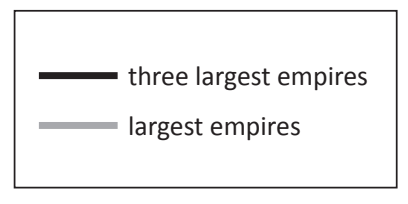
three largest together (upper curve). Time is compressed for earlier periods on $\mathrm{x}$ axis; $\mathrm{y}$ axis logarithmic.

Source: Myrdal 2012. 


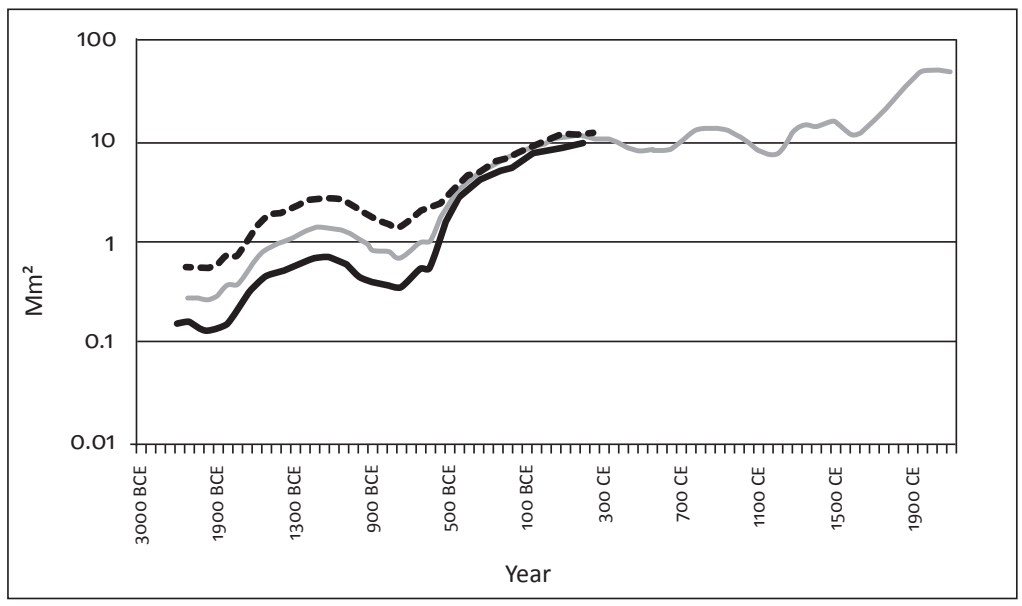

Figure $4 \mathrm{~b}$. Areas of control and under direct influence, curve based on atlases from around 2000.

Note: Lower curve under direct control, upper

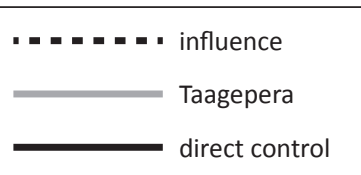
curve area of influence, middle curve Taagepera's estimate. Later part of the curve similar to Taagepera's curve, but must also be problematized (see text). Time is compressed for earlier periods on $\mathrm{x}$ axis; $y$ axis logarithmic.

Source: Myrdal 2012.

The atlases today do not give any basis for such estimates. Perhaps future generations of historical atlases will incorporate such intricate measurements. Still, the two different patterns in Figure $4 \mathrm{~b}$ will remain a result that one must relate to. In an earlier period we had a more gradual, floating structure with regard to states and state control.

An interesting conclusion might be that if we have different patterns in older periods a new pattern may emerge. If the whole world is divided up into states, as it is today, a number of alliances will be formed. Such alliances will develop into very firm structures and if in the future historians want to understand late twentieth-century politics, a map showing NATO and the countries of the Warsaw pact would probably be more instructive than a map showing different nations. One might describe this as a return, on a new and 
higher level, to the phenomenon of core and influence zones (e.g. with the Unites States as the core and NATO as the influence zone).

Another conclusion based on these findings is that earlier graphs tended to underestimate the changes in the last centuries BCE. State power grew more than was previously thought, and a politically new landscape of increasing state control over nearly all of Eurasia followed.

\section{Other measurements of states and empires}

The next source-critical problem to be treated is that a single indicator yields a simplification. Thus one should strive to present several indicators of the same phenomenon. To phrase it differently: one can produce differing results by changing the conditions for the calculations. Two such different methods of computing are first, to look at the largest states' share of the population, and second, to look at all states rather than just the top three (Myrdal 2012).

Population is an important unit of measurement because it indicates a state's ability to organize a social structure. I calculated the two largest states' share of world population (see Figure 5). For an analysis of the development of human societies this is a more important measurement than the ability to control territory. Taagepera (I997) made such an attempt, but it is difficult to identify individual states. His calculations, which show the same tendencies I observe, are seldom referenced.

I have to make a small digression about population estimates. Like other historians, I use McEvedy and Jones as the basis for calculations, though their book was published nearly four decades ago (McEvedy \& Jones I 978). The advantage of McEvedy and Jones is that they present calculations for every country in the world, with at least one page of discussion and often more about what the figures are based on. The reader also learns about the available sources.

Recent discussions about the history of world population often compare alternative estimates (see the website of the United States Census Bureau), but mainly refer to publications from the I970s (except for the last 200 years where newer surveys exist). In an attempt to construct data for economic development over long 
periods Angus Maddison made estimates, but they were based on a rather small number of older references to demographic literature (Maddison 2007: 230-240). I will try to identify the weakness in the data presented by McEvedy and Jones, which is seldom done by those who utilize these data.

In comparison with other estimates, McEvedy and Jones often give low figures, especially for older periods. To understand why, something must be said about McEvedy, who was the leading author. He produced a number of historical atlases, also widely used, as he had a talent for summarizing knowledge and presenting it in a condensed and easily understandable manner. McEvedy was a psychiatrist by profession, but his passion was history (Oles 20 I I). Late in his life he worked on a book about towns in the Roman Empire, using the same method as in his population book. For I 20 cities he discusses a possible size, mentioning estimates by other scholars. His own estimates tend to be cautious. An example is Rome itself, where the figure he gives is far below other estimates (McEvedy 20 I I: 3 I9-320).

We are in great need of a new compilation of the kind made by McEvedy and Jones. It would affect many branches of world history, for instance GNP, which Rodney Edvinsson discusses in one of the chapters in this volume.

The relative proportion, which I have used, would be a more reliable measurement than absolute numbers if McEvedy and Jones were consistent in their low estimates during a certain period. However, it seems that they underestimated Africa and America more than Europe and Asia (following their precautionary principle - less was known at that time about these parts of the world). Thus the relative proportion given below would tend to be higher than the actual proportion, as none of the states included were situated in Africa or America. This overestimation is not dramatic, as Asia always has had by far the largest share of the world population and was home to the most important empires. The uncertainty margins are nevertheless so large that I only included the largest empires (more than c. I 5 per cent of the world population).

One cannot get further than the best available tertiary literature allows (without starting a project to replace it). At the same time, this calculation, with its weaknesses, allows us to reach a more rele- 


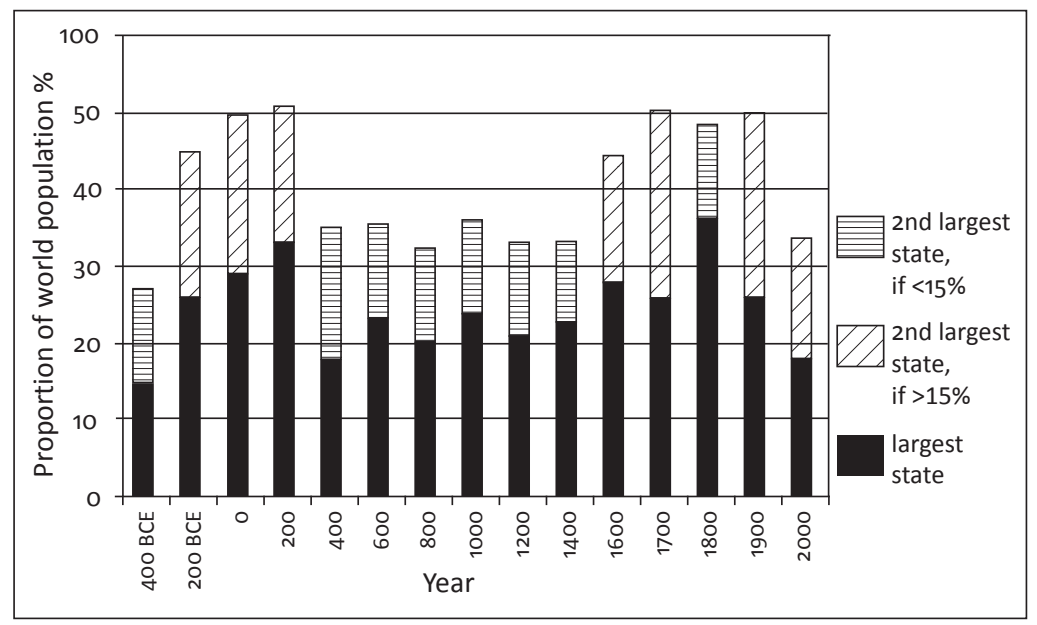

Figure 5. Relative populations of the two largest empires or states. The two largest states' approximate proportion of world population at the times indicated. Note: The second largest state is represented by a pattern of horizontal lines if it is less $(<)$ than c. I 5 per cent; if more $(>)$ it is marked with diagonal lines. The bars with horizontal lines, less $(<)$ than I $5 \%$, are all represented as $15 \%$, but actually most of them ought to be shorter as they reach lower percentages. The reason for not giving precise numbers below I $5 \%$ is that the uncertainty of these figures increases for smaller empires. Source: Myrdal 20 I 2.

vant conclusion than one based only on area. There is no tendency that a few empires increasingly dominate the world.

The result of the calculation was instead a long wave, with two crests: one during the period $200 \mathrm{BCE}-200 \mathrm{CE}$ and the other in the period $c$. I 500-I 900 . The two largest states' share of the total world population was about $45-50$ per cent during these peaks. In the intervening periods, it was about a third of the global population, which is also true today.

The first conclusion from this is the surprisingly large share of the world population that was organized under empires in the centuries around the beginning of our current era. In the Eurasian corridor along a latitude of 40 degrees $\mathrm{N}$, not being subordinate to an empire was actually atypical. Then this pattern broke down, and the empire became just one form of state organization among others. There is no historical trend towards a greater concentration of population in major empires. 
The other alternative estimate was the entire area under state control, and for this I have used two newer atlases. It turns out that there is a substantial increase in outright state control of the Earth's surface over the last 200 years, from half of the surface to the whole world. Colonial powers increased their share, which gave rise to subjugated nations' desire for liberation. What happened was that social organization increased, which was certainly not accomplished by the colonial powers alone, but was a result of social and economic change in general.

Table I. Area controlled by states as a per centage of the total landmass, based on two atlases from the late i990s.

\section{Haywood Black}

\begin{tabular}{|c|c|}
\hline $2500 \mathrm{BCE}$ & I \\
\hline $2000 \mathrm{BCE}$ & I \\
\hline $500 \mathrm{BCE}$ & 8 \\
\hline $250 \mathrm{BCE}$ & 12 \\
\hline 0 & 13 \\
\hline 250 & \\
\hline 500 & 13 \\
\hline 800 & 19 \\
\hline 1000 & 20 \\
\hline 1200 & \\
\hline 1300 & 32 \\
\hline 1400 & \\
\hline 1500 & 23 \\
\hline 1600 & 29 \\
\hline 1700 & 49 \\
\hline 1800 & 69 \\
\hline 1850 & 74 \\
\hline 1900 & 96 \\
\hline
\end{tabular}

Source: Haywood I997; Black I999; cf. Myrdal 20 I2: 4I. 
To conclude this critical assessment of measuring states, three accompanying patterns appear. First, the three largest states controlled an increasingly large part of the landmass - today, however, the curve has turned downwards. Second, the two largest states' share of the total world population has remained fairly constant over the last 2,000 years, with fluctuations between one third and one half. Third, over the past two centuries the entire earth has come under state control. The concomitant increase of medium-sized and small states is the reason that the area belonging to the three largest states has decreased during the last decades.

Different pictures emerge, and all of them contribute to an overall interpretation of the long cycles in state-forming processes. The leap forward in the centuries between 500 and Ioo BCE was dramatic, but just as dramatic was the inclusion of the whole world under state control in the period c.700-I900.

These measurements of states and empires are based on what I have labelled tertiary sources, mainly atlases. In the future, when population estimates have been compiled and when atlases consistently work with core areas and areas of influence for earlier states, better data will become available. Another improvement would be atlases that also include such estimates for later periods, taking alliances and dominance into account. My investigations are thus only a part of the necessary process of methodological development in measuring states and empires.

A further question relates to the definition of a state. Most of these maps and calculations work with a simple definition: a state is a political entity (a "government") which controls a territory. Indeed it could be claimed that a state in $2000 \mathrm{BCE}$ is quite different than a state in $1500 \mathrm{CE}$. A refinement of the definition would probably result in several overlapping graphs for different periods. Here we are faced with limitations in the source material, historical atlases that are tertiary sources. The question about categories will be crucial in the next section about popular rebellions, where I have created the dataset by also utilizing secondary sources. 


\section{Categories and rebellions}

I now turn to the essential question about working with strictly defined categories, which is a core issue of source criticism relating to measurable indicators.

Categories being compared must be similar. Lack of consistent and comparable units makes comparison futile. In comparative world history geographical units should preferably be of equal size. We cannot compare England with all of China. Instead, for example, the Yangtze delta and a European nation such as England give a more balanced comparison (Pomeranz 2000: 7). In general synthesis this is not a problem as all regions are included. Instead the definition of what to compare is crucial. Here I want to highlight that the goal is not to acquire as much evidence as possible, but to obtain comparable units. Sometimes a smaller number, carefully analyzed, is more revealing than a larger number of cases. My example will be popular rebellions in Europe from the High Middle Ages to the early modern period.

A large number of cases allow more complex calculations, and there is a lower limit to what can be considered as providing a basis for measurability. The advantage of a smaller number of cases is that a stricter selection can provide greater similarity between the cases. It is also a means to avoid assigning better explored regions greater weight in comparisons. Moreover, one can discuss the individual cases in detail.

That the cases may be discussed in detail establishes similarities to comparative world history. The crucial difference is that here the cases are selected through an all-inclusive survey. A common pattern in earlier scholarship has been to present some well-known popular rebellions, overestimating the significance of those in France and England, and then perhaps supplement the discussion with German cases from the end of the Middle Ages. To survey Europe in its entirety means that important cases in Eastern Europe and Scandinavia are included and discussed. Another part of such a strict selection of cases is that numerous rebellions that do not meet the criteria are excluded. In well researched areas too, some cases often mentioned in the scholarly literature have to be excluded.

States cannot be understood solely by investigating forces that held them together. It is obviously equally important to understand 
the forces that tended to break them down and divide them. One of the occurrences that scholars have tried to count is the number of wars. Since major wars are mentioned in chronicles, the source material allows such calculations as soon as we have written sources.

Pitirim Sorokin was one of the first to attempt this, and since then there have been several compilations. William Eckhardt's calculation is one of the most ambitious (Eckhardt I992). Similar calculations have formed the basis for other conclusions such as Steven Pinker's reasoning about the decreasing use of violence (Pinker 20 I 2). I will argue that a deeper understanding of large-scale conflicts has been hampered by methodological shortcomings.

Eckhardt's figures are not based on a selection of cases with clear boundaries between different types of conflict. He does not provide descriptions of the individual conflicts. There are simply too many cases in the statistics, and the conclusions are doomed to be sweeping. With clear demarcation of a manageable number of cases, one can cross the boundary between the quantitative and the qualitative and achieve a descriptive catalogue. Sorokin is in fact easier to work with, as he has a catalogue with a description of all conflicts. He also separates wars from civil wars, though in the latter category he mixes strife within the upper class with popular rebellions, which makes his results blurred (Sorokin I937-I94I, 3: Appendix to part three, 579-620).

I will focus on one type of conflict: popular uprisings. There are several compilations of revolts, all suffering from the problem of mixing large and small. Hugues Neveux (1997) published an ambitious catalogue of more than 150 revolts in Europe during the period I300-I675. In his mixture, pillaging a monastery is one of the smallest conflicts and nationwide rebellions like the German Peasants' War are among the largest. His catalogue provides information, but it is difficult to use as an analytical instrument.

Another example comes from Geoffrey Parker's book from 2013 about the crisis in the seventeenth century. He argues that political unrest around I635-1666 has to be understood in a worldwide perspective, partly as a result of economic problems caused by climate change. As a starting point, he enumerates 49 "major revolts and revolutions" of which 22 led to regime change (Parker 20 I 3: xviii-xix, map and list). The list contains rather disparate political revolts. The 
Danish Revolution in I660 was a coup carried out by the King to gain more power. The Pequote War was an armed conflict between American Indians and English settlers. The rebellion in China did not last a single year (as one might believe from the table), but went on from $c .1636-1646$ and was one of bloodiest popular rebellions ever, with millions of casualties. The Goa rebellion against Portugal was a religious movement, when the Christian community decided that they would not submit to Portuguese dominance. And so on.

Of course Parker is aware of this mixture. In another and much earlier publication he has made a distinction between areas affected by war, areas affected by popular revolt and areas affected by political rebellion (Parker 1978: 5, map). One must take into account that his intention in the 2013 book is to paint a picture of general unrest, and he describes many of the conflicts in detail. Nevertheless, we cannot be sure that he is correct without a delimitation of cases and comparison with other periods using the same criteria.

A set of criteria must be established when conflicts of a similar kind are identified. To separate popular rebellions from other civil wars, one criterion must be that broad strata of the population take part and that they have some influence over the rebellion. A key indicator to estimate the influence of the common people is to look at the demands made during the uprising. Another indicator is to examine the composition of the army, but this indicator is weaker because peasants could be involved in conflicts between leading groups in the society, being recruited as soldiers. Another criterion to identify the major revolts is to examine certain kinds of violence. This is a relevant criterion for the period I have chosen, since armed rebellion was the option available for common people to put pressure behind their demands. In a time series stretching into later periods, and especially into contemporary times, that would not be a relevant criterion as it would exclude, for example, large strikes.

Visibility in the secondary and tertiary sources is essential and thus smaller conflicts have to be excluded. The assumption is that large rebellions are always mentioned in national surveys of political history. Smaller conflicts can be enumerated for particular regions if a scholar has endeavoured to go through all the documents and look for them. (I have done that for medieval Sweden, and know that it 

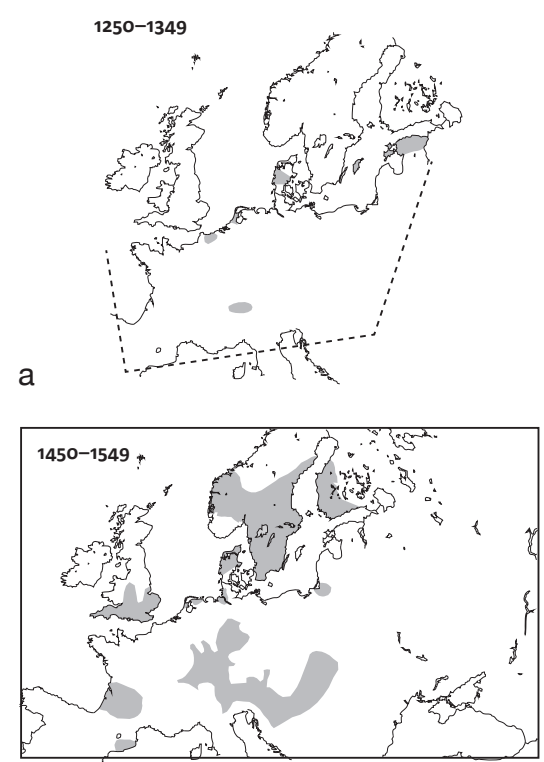

C

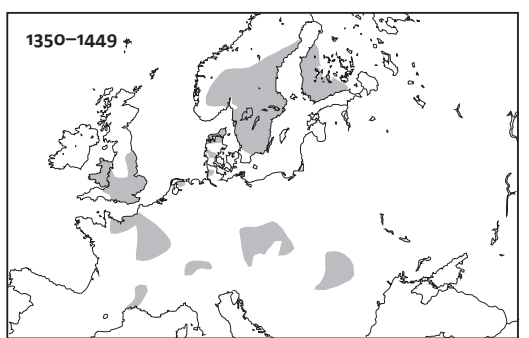

b

Figure 6a-d. Large popular rural rebellions I 250-I650 in Europe. Source: Myrdal I995; Myrdal I999.

is extremely cumbersome work). Such surveys cannot be included in an interregional comparison, since this would result in an overrepresentation of regions where scholars have carried out such surveys.

To present the goal for the rebellions is important for an analysis. A religious movement is not the same as a nationalistic movement or a rebellion among peasants against oppression by the king or local lords. Certainly goals are mixed, but identifying them facilitates discussion of long-term trends. This also implies a descriptive text about every case, which works against including too many cases.

For Europe I have put together such a catalogue of large popular rebellions from the eleventh to the seventeenth centuries, using the aforementioned criteria (Myrdal I995). I also added the restriction that the rebellions should be rurally based, thus excluding some urban revolutions. The source materials, besides a number of books specifically about rebellions, consisted of national histories published in languages that I could read. In the catalogue, every conflict was described, which is the same method McEvedy and Jones used for population. 
Conflicts, as I defined them, did not exist until a state apparatus was established. Between I Ioo and I 250 a number of conflicts were related to the spread of feudalism to the European periphery. In Scotland, Scandinavia and the Baltic states the conflicts had elements of popular rebellion but also resembled conflicts among the upper classes and even conflicts between regions. It was not until around $\mathrm{I} 250$ that a kind of popular rebellion comparable to later equivalents appeared over large areas of Europe.

The catalogue detailed about 80 large popular and rural rebellions that took place during the period I250-I650. After an increase from $c .1250-1350$, the number of large rural rebellions was fairly constant, about 20-30 per century until the early seventeenth century. When they were mapped, patterns emerged more clearly. The increase from the mid-fourteenth century is clearly evident on the series of maps.

Another interesting fact is that large rebellions in the late medieval period occurred in the economic and political core areas of Europe, whereas at the beginning of the early modern period there were instead more large rebellions in the periphery. (Figure $6 \mathrm{a}-\mathrm{d}$. For the earliest period, Russia on the eastern periphery is excluded due to lack of sources.) The core areas were also those where a strong state was established, partly as a reaction to largescale popular rebellions.

Feudal rent was in focus directly after the Black Death, but then state taxation and control over the administration of the nation became more important (Myrdal I995; Myrdal I997). A sequence of rebellions with increasing demands from below for influence during the late Medieval period came to a halt with the establishment of strong states in the core of Europe during the sixteenth century. The strong state was the main deterrent to large popular rebellions in these parts of Europe.

If this study were to be extended in time and space to include the whole world, criteria would obviously have to change to cover greater diversity. Another, more feasible method might be to establish a complementary time series, such as before and after the establishment of the state. This prospect offers very interesting work on methodology. Instead of one long time series of rebellions (or wars, or conflict of 
other kinds), we have to identify several series, overlapping each other and illuminating different aspects. Such a methodological approach is probably also valid for several other phenomena where we want to create a basis for long and worldwide time series.

\section{Critical test of a theory - the axial age}

In the following two sections I apply the source-critical requirements I have introduced in the preceding sections. I focus on an easily measurable aspect of the theory, starting with indicators that include a number of cases, and then turn to a more strict selection of cases.

Theories are a blessing. Without them we could not reflect on history. They do, however, have to be tested. A provocative theory will often instigate research, but sometimes theories are not tested using stringent methods and verified data. One argument might be that such grand theories are impossible to test. That may be correct if we look at the theoretical structure as a whole, but elements of it can always be tested, and if it is proved that several element are incorrect, the rest of the theory is in jeopardy.

The example will be the theory concerning the axial age. A real test would require a much longer text, and I will only hint at possible ways to test parts of the theory. The relationship to previous examples is that states are not held together solely by military power; even more important is legitimacy. A loyal bureaucracy and an ideology that persuades individuals and groups to accept and even support the state are necessities. Large-scale changes of socio-political structures normally go hand in hand with ideological shifts. The theory of an axial age, however, goes far beyond ideologies for governing a state.

Before I delve into the theory itself it must be admitted that it does not belong to mainstream world history. In two extensive overviews covering more than 700 pages each, the axial age is mentioned just once (Northrop 20 I 2, in connection with Eurocentrism) and twice (Bentley 20II). On the other hand, its adherents are a confident group, and lately their ideas have reached a wider audience through the eloquent writer Karen Armstrong (who is not a member of this scholarly coterie).

To summarize the theory: nearly 70 years ago the philosopher 
Karl Jaspers noticed that between the eighth and second centuries $\mathrm{BCE}$, with a focus around $500 \mathrm{BCE}$, a number of large-scale intellectual systems were created, both religious and philosophical. In this intellectual leap forward, people in different parts of Eurasia started to consider intellectual phenomena such as contradictions and especially transcendence. The term "axial" refers partly to the axis through Eurasia where these ideologies took form, from China to Europe, but the core of the metaphor is that these new ideas constitute an axis for all intellectual history (for an interesting visual presentation of the theory see Holenstein 2004: 50-5 I.)

This has been developed by several generations of scholars. Among the leading ones is S.N. Eisenstadt, who emphasized the tension between the transcendental and the mundane as a result of the emergence of an intellectual elite. With the formation of a more complicated society, social protest, solidarity and the social division of labour became important issues (Eisenstadt I986: I I). Utopian ideas attracted followers imagining another world order.

Björn Wittrock has proposed a definition. He sees the axial age as the emergence of an institutionalized critical reflexivity together with historical awareness about change and the possibility of change. Arenas for intellectual discussion were established. Wittrock also emphasizes that different but parallel paths were followed, which gave the new way of conceptualizing the world a partly different content in various large regions such as Europe, West Asia, South Asia and China. This follows from what he labels "cultural crystallization", when structures for creating order and teaching knowledge were established (Wittrock 2005).

A partly different approach has been suggested by Karen Armstrong. Her interpretations can fairly easily be combined with the group of ideas discussed above. She takes her starting point in the "golden rule" (one should treat others as one would like others to treat oneself), and aims to describe how this basic moral approach developed during the axial age. Jesus was only one of the later prophets who advocated this, building on a long tradition (Armstrong 2007).

There are also opponents. Jan Assmann, for one, has argued against the idea of one crucial moment with a common outcome, asserting that we must identify changes before and after this period (Assmann 20 I 2). 
Scholars working with the axial age today do not, in fact, focus solely on the first great leap forward, but also on other fundamental and structural intellectual leaps. The period around I000-I 300 in Eurasia and the European Enlightenment around I600-I 800 have been regarded as such epochs of intellectual change (for examples, see chapters in Arnason \& Wittrock 20 I I).

Neither supporters nor opponents have exposed the theory to stringent tests with quantitative data. Here one aspect is chosen that tests the underlying prerequisites for the theory rather than the theory as such. My question is: are there periods - long or short - when the development of ideas and ideologies is more rapid than during other periods? I will avoid the question of how rapid a change must be to justify the term "revolution", a discussion that seems pointless to me. If such periods can be identified it makes the idea of an axial age more probable. The next step would be to analyze their significance, which would demand a selection of texts to be closely examined.

Attempts to identify periods of intellectual change with quantitative measurements have been made, though not directly in connection with this debate. An example is Jan Luiten van Zanden. His question was how a society based on knowledge developed. A main indicator is the quantity of manuscripts and published books in Europe for the last I, 500 years. A decline occurred around the middle of the first millennium an increase began in the eighth and ninth centuries. After a short stagnation this continued to a peak from the eleventh to the thirteenth century. Then a new rapid increase started with mass-production of printed books from the end of the Middle Ages, and the increase continued into the sixteenth century. The next increase, which was a leap, came from the mid-eighteenth century and onwards (van Zanden 2009).

Another grandiose attempt was made by Pitirim Sorokin. One of his goals was to identify a large intellectual cycle where the focus went from more materialistic to idealistic and the reverse. He registered thousands of philosophers, whom he labelled "thinkers", according to certain main schools of thought and ideas. Here I am only interested in the quantity of "thinkers" he registered. He graded them according to influence and presented them in appendices, using the ninth edition of the Encyclopædia Britannica, although he was aware that this 
overestimates Anglo-Saxon thinkers (Sorokin I937-4I, 2: I 43, I 52), and also two American, one British and two German philosophical lexicons published in the I920s (Sorokin I937-4I, 2: 635). His accounts apply only to the West. In his tables and diagrams we see a long period of high numbers from the fifth century BCE to the fifth century $\mathrm{CE}$, then a shorter peak in the eleventh and twelfth centuries, and from the seventeenth century an ongoing upward trend (Sorokin I937-4I, 2: 29-3 I, I 85-I 89 and 4: 353; Sorokin I957: 288-289).

An interesting fact is that Sorokin and Jaspers were contemporaries (though without referring to each other). Jaspers was less Eurocentric, but did not substantiate his theory, as Sorokin attempted to do.

A recent and corresponding publication gives another basis for calculations. Randall Collins has registered nearly 3,000 philosophers during the last 3,000 years and the intellectual connections among them (Collins 1998). His goal is to identify the flow of ideas, and he gives all his data in diagrams and appendices. The sources are modern books about the history of philosophy, published according to different regions. He emphasizes the value of measuring philosophers' influence long after they were active (Collins I 998: 58-6I).

For China he uses nine different publications, all of them published from the I950s to the I980s, seven in the US and Britain, two in Singapore and China. As a source of additional information, he refers to eighteen other books published during the same period. For Greece in antiquity he uses a mixture of texts from that period and books from the twentieth century. Besides three historical sources he draws on eleven books from I9I 5-1990 as the main source, and twelve additional scholarly books from the same period as supplementary sources (Collins I998: 950). He also points out that the numbers for China and Greece cannot be directly compared. He has similar sources for other regions and periods such as India and early modern Europe.

Collins is a typical example of how a tertiary source is limited by the quality of secondary sources (which cannot be examined here). Though he strives to give the same weight to every part of the world that produced philosophers, he is limited by having to rely on texts written in the languages he has mastered, which in practice means texts from Anglo-Saxon countries.

Collins establishes a hierarchy of philosophers, distinguishing 
between major, secondary and minor figures. His categorizations are based on the space they are given in the books used as sources. Collins focuses on the major figures.

If crucial periods exist, the number of philosophers remembered today should be larger during those periods, assuming the thinkers made valuable contributions. Collins argues that minor philosophers often lack "originality and depth": they are followers, though in their own time they may have been considered major figures (Collins I 998: 62-63). To him only major and secondary philosophers produced real change in the world of ideas.

Collins discusses certain periods as hotspots. One such is Greece between 500 and $265 \mathrm{BCE}$ with fourteen major and thirty-one secondary philosophers. Another is China from 365-235 BCE with five major and nine secondary philosophers (Collins I998: 57-59). These periods stand out distinctly from other periods: the figures seem to be in line with the notion of an axial age, though it occurs later than Jaspers proposed.

Collins does not expend much effort on discussing all the hundreds of "minor" philosophers. As a further test I have counted all the names in his tables and diagrams for China between 500 BCE and $700 \mathrm{CE}$. From this it seems that the number of philosophers mentioned in modern works is fairly constant, but with a dip around the beginning of our current era (see Table 2). A calculation for Greek and Roman philosophers shows a similar pattern, but with an expected dip in late antiquity.

The explanation for a constant number of minor philosophers could be the institutionalization of an earlier breakthrough. The minor philosophers did not formulate new ideas, but they transmitted accepted ideas in an established intellectual structure.

The decrease in Europe in late antiquity is easy to explain. The decrease in China around the beginning of our era would require a longer discussion. Here I only point out that during this period we see one of the most dramatic intellectual upheavals in China. Under emperor Wang Mang (9-23), an usurper who did not belong to the royal family, a number of reforms were tested. Needham has mentioned that historians of science have a weakness for Wang Mang because he was interested in science and called together the 
first assembly of experts. After he was overthrown all his reforms were rescinded (Needham I954: I09-I I0). This could be significant for the later recognition of minor philosophers from this period.

The methodological conclusion is that a qualitative analysis is necessary. The numbers in the table give a rough indicator of a long trend of a rather constant number of minor philosophers remembered in much later surveys. A further refinement of these data would be to make a more strict selection, perhaps using the methods suggested by Sorokin: selecting them according to the main content in their preserved publications.

Table 2. All philosophers, mainly "minor", in China mentioned in Collins I 998.

$\begin{array}{cr}500-400 \text { BCE } & 20 \\ 400-300 \text { BCE } & 17 \\ 300-200 \text { BCE } & 27 \\ 200-100 \text { BCE } & 28 \\ 100-1 \text { BCE } & 9 \\ 1-100 & 5 \\ 100-200 & 13 \\ 200-300 & 25 \\ 300-400 & 27 \\ 400-500 & 24 \\ 500-600 & 28 \\ 600-700 & 25 \\ 700-800 & 15\end{array}$

Note: As some philosophers were active over the turn of a century, I have assessed which century they belong to.

Source: Collins 1998. In his catalogues for China he lists 25 major philosophers, 6I secondary and 356 minor from 535 BCE to I 565 CE. For Greece he has 28 major philosophers, 68 secondary and 237 minor from 600 BCE to 600 $\mathrm{CE}$. He has corresponding figures for other parts of Eurasia, such as India. In all, more than 2600 persons are mentioned (Collins 1998: 77).

The number of philosophers only provides a framework for an interpretation. Data from Sorokin and Collins indicate that during a long period, mainly after what is normally considered the peak 
period of axial change, a relatively large number of thinkers/philosophers were active.

An in-depth analysis would require working with a restricted number of texts to see if reflexivity and historical awareness become more prevalent, preferably also using quantitative methods. A very important factor is then the selection of texts. In the next section I will look closely at one category of texts.

\section{The axial age exemplified by agricultural treatises}

The emergence of natural science, which started to replace natural philosophy and religious thought, is a part of the Axial breakthrough (Wittrock 2005: 53). Texts on agriculture are the first extant genre about science. I have made a survey of all texts before I 500 (Myrdal 20I4). Here I will address their number.

In my investigation of these texts I also discuss their content, but then in terms of a question not directly related to the theory of an axial age. As they are a main source for agricultural history, my question was how closely they relate to actual agricultural praxis. The answer was that to a large extent they describe a reality, though with some bias towards larger estates.

To find comparable units by strict delimitation is essential. Only original works that had been preserved were included, since they were the only ones that could be checked. Early translations are certainly an indicator of interest in these issues, but are often harder to date. Only longer treatises were included (with a lower limit of Io,ooo words/Chinese characters). This was based on the assumption that longer texts were mentioned in secondary and tertiary sources, which had to be the basis for my compilation.

If shorter texts had been included there would have been a bias favouring regions that have elicited more extensive research about agricultural history. One of the best-known medieval agricultural treatises was written by Walter Henley in England in the thirteenth century. It contains fewer than Io, ooo words, and its influence was restricted to England, compared with, for instance, the Italian Crescentiis, who in I 3 I 5 wrote a long text that continued to be copied and referred to until the end of the Middle Ages; it was even 
translated into French. One reason Henley's text is mentioned so frequently is that in modern agrarian history regarding the Middle Ages England is predominant and often serves as a role model for research on other countries. In Table 3 Henley is not included.

After I 500 the number of agricultural treatises increased worldwide. In Europe, explosive growth followed, especially of printed texts, and a further leap came in the eighteenth century.

Table 3. Number of extant agricultural treatises by century.

\section{Rome- China (and The Islamic Europe India Byzantium East Asia) World}

\begin{tabular}{|c|c|c|c|c|}
\hline 200-100 BCE & 1 & & & \\
\hline $100-1$ BCE & 2 & & & \\
\hline $1-100$ & 2 & & & \\
\hline $100-200$ & & & & \\
\hline $200-300$ & & & & \\
\hline $300-400$ & I & & & \\
\hline $400-500$ & I* & & & \\
\hline $500-600$ & $2^{*}$ & 1 & & \\
\hline $600-700$ & 1 & 1 & & \\
\hline $700-800$ & & 2 & & \\
\hline 800-900 & & 1 & & \\
\hline 900-1000 & I* & & & \\
\hline $1000-1100$ & & 7 & 3 & \\
\hline $1100-1200$ & & 5 & 2 & \\
\hline |200-1300 & & 6 & 2 & \\
\hline |300-1400 & & 4 & $5+$ & 2 \\
\hline $1400-1500$ & & $2 \#$ & 1 & 2 \\
\hline
\end{tabular}

Note: During antiquity, Italy is included in "Rome-Byzantium" and during the Middle Ages in "Europe". Post-eleventh century, Byzantium essentially does not exist as a separate cultural sphere, although it did exist as a country for a few more centuries.

* Datings are uncertain for the late classical-Byzantine period and for the Indian texts. + Including one Persian work. \# Both from Korea.

Source: Myrdal 2014. 
In the case of China, it seems that texts from the Han dynasty (c.200 BCE-200 CE) may be as many and as long as those from the Roman Empire, although the Chinese texts have not been preserved. Some of the oldest ones preserved were of an impressive length: e.g. Columella 2 10,000 words (6o-65 CE) and Palladius 80,000 words (c.400-425). A second increase came during the period I000-I 300. The longest European text, with 220,000 words, was by Crescentiis in I3 I 5 , and the longest Chinese text, with I I0,000 characters, was by Wang Chen, $c$. I 3 I 5 (in older Chinese a character normally corresponds to a word). Both were surpassed by the longest agricultural treatise in the medieval world, by Ibn al-Awwam, with 500,000 words, written in Spain in the twelfth century and based on the scholarship of the Islamic countries.

These texts represent an accumulation of knowledge and an interest in such topics among intellectual groups, essentially the upper class. Several of the texts, but not all, are related to periods of agricultural expansion. In periods of threats to agriculture, texts were written to preserve knowledge built up under preceding periods, such as the text by Wang Chen written under the reign of the Mongols (Yuan dynasty).

Agricultural treatises are just one category of texts with detailed descriptions of natural phenomena, but they indicate that the breakthrough for this intellectual endeavour came after the axial age proper. They belong to the empire-building periods in Rome and China, when a large upper class and a substantial group of bureaucrats could form the basis for such an interest. A second crucial period came around I000-I300, and a third leap in the sixteenth century. Without a strict limitation the importance of Europe would have been overestimated.

Summarizing my attempt to test the hypothesis about crucial periods of intellectual change, the evidence indicates that they exist. It has yet to be established, however, that there was a specific Axial period around 500. Rather, the data presented here point to the period after the formation of the first larger states in Eurasia as more crucial: this was a period of rapid change in economies and political structures. A second Eurasia-wide intellectual change seems to have occurred in the centuries around and after Iooo CE, again a period of economic and social restructuring. An alternative theory 
would then be that large intellectual leaps tend to be coordinated with periods of general changes in the society.

A basic idea in the Axial theory is that certain ideas are launched during one period of time. An alternative hypothesis is that such ideas are formed more stepwise during several periods. One also has to consider the possibility of setbacks and then a reformulation of the core ideas.

I have not tried to quantify core ideas such as reflexivity - but I claim that it would be possible to make such quantification in a strictly selected number of texts spread out over a long period.

A major objection is that preserved written sources form a restriction for testing the theory. Other indicators have to be utilized. For instance, art and buildings could be such sources. The erection of large buildings for religious purposes in all of Eurasia during the centuries around Iooo CE is a further indicator of a crucial change of belief systems.

My findings challenge the idea of a changed mentality around 500, pointing to a later period and different context for the major change. Indeed, an empirical investigation with measurable estimations of the core ideas in a restricted number of texts still needs to be done.

\section{Conclusions}

I have mainly considered inclusive syntheses for world history and have focused on graphs and tables that can support general syntheses and grand theories. Below are my suggestions for improving the standard of these.

I) The first step is to define a measurement. It is certainly justifiable to illustrate a theory or hypothesis with a sketch. The synchronoptical graphs widely distributed today show a Eurocentric bias. Future synchronoptical graphs may have a less pronounced Eurocentric bias, but if the measurement remains subjective they cannot be used as analytical tools.

This critique also applies to several of the maps and graphs used in world system theory. They are presumably not as biased as the graphs I analyzed - but it would be preferable to find indicators that could be a basis for showing contacts between regions. 
2) The next step is to try to use the latest research findings. Tertiary sources will always be lagging behind the secondary literature - and both change. Data based on tertiary sources, such as historical atlases, must therefore be renewed constantly.

The arc of the largest states is just one example, and one of the most desirable new databases would be population statistics. Data compiled and discussed at length, country by country, based on the newest demographical research, would produce a new reference work for world history.

3) It is inherent in quantitative synthesis, maps and graphs that they only show one aspect, and thus scholars must seek several indicators that will show different aspects of the course of events. In such a pluralistic approach different disciplines could work together. For instance, archaeology and history could together reconstruct a history of world trade over millennia by using several indicators. This would also reveal different aspects of how long-distance trade has developed.

4) To collect as much evidence as possible is tempting and has advantages, but it could lead to blurred results, which are difficult to interpret. A strict limitation leading to a smaller number of cases will often allow a closer analysis.

Such a restriction can be combined with detailed descriptions of every case, and in this respect it has similarities with comparative world history. However, the difference is that the limited number of cases in a global survey still requires a complete and inclusive search for such cases.

5) Even grand theories can be tested by selecting phenomena related to the predictions of the theory. My attempt to test the theory of the axial age seems to indicate that the process was more complex and diverse than what was anticipated - but also that elements of the theory, about periods of more rapid change, probably are correct.

Accumulating data to support or refute a theory is not the only way to test it. Instead it is better to have fewer criteria that are better controlled and discussed. Two doubtful graphs or diagrams do not give more support than one that is carefully selected and scrutinized. 
Finally, I want to return to what will always be a main method in world history, narrative description. I have not argued for replacing this, only for developing methods so that this kind of world history could be better controlled, refuted or substantiated. To end with a quote from Popper, just as I began this chapter, I concur with his claim that if a theory "passes certain tests it will be better than some other theory" (Popper I965: 217).

\section{References}

Adas, Michael. 20 r 2. "Comparative History and the Challenge of the Grand Narrative", in Northrop, D. (ed.), A Companion to World History. Malden, MA: Wiley Blackwell.

Armstrong, Karen. 2007. The Great Transformation: The Beginning of Our Religious Traditions. New York: Anchor Books.

Arnason, Johann P. \& Wittrock, Björn. (eds.). 20 I I. Eurasian Transformations, Tenth to Thirteenth Centuries: Crystallizations, Divergences, Renaissances. Leiden. Brill.

Assmann, Jan. 20r 2. "Cultural Memory and the Myth of the Axial Age", in Bellah, R. N. \& Joas, H. (eds.), The Axial Age and Its Consequences. Cambridge, MA: The Belknap Press of Harvard University Press.

Barraclough, Geoffrey. (ed.). I978. The Times Atlas of World History. London: Times Books.

Bentley, Jerry H. (ed.). 20 I I. The Oxford Handbook of World History. Oxford: Oxford University Press.

Black, Jeremy. I997a. Maps and History: Constructing Images of the Past. New Haven. Yale University Press.

_ i997b. Maps and Politics. London: Reaktion Books.

- (ed.). I 999. Atlas of World History. London: Dorling Kindersley.

Cancik, Hubert \& Schneider, Helmuth. (eds.). 1996-2003. Der neue Pauly: Enzyklopädie der Antike I-IS. Stuttgart. Metzler.

Collins, Randall. 1998. The Sociology of Philosophies: A Global Theory of Intellectual Change. Cambridge: The Belknap Press of Harvard University Press.

Conrad, Sebastian. 2013. Globalgeschichte: Eine Einführung. München: C H Beck.

Eckhardt, William. 1992. Civilizations, Empires and Wars: A Quantitative History of War. Jeffersson, NC: McFarland \& Company.

Eisenstadt, Shmuel Noah. 1986. "The Axial Age Breakthroughs - Their Characteristics and Origins", in Eisenstadt, S.N. (ed.), The Origins and Diversity of Axial Age Civilizations. Albany, NY: State University of New York Press.

Fournet, Louis-Henri. I99I. Tableau synoptique de l'histoire du monde pendant les cinquante derniers siècles. Antony: Sides.

Grosser Historischer Weltatlas. Erläuterungen I-4. 1976-1996. München: Bayerischer Schulbuch-Verlag.

Halsall, Guy. 2007. Barbarian Migrations and the Roman West, 376-568. Cambridge: Cambridge University Press. 
Haywood, John. (ed.). I 997. Atlas of World History. London: Cassell.

Holenstein, Elmar. 2004. Philosophie-Atlas: Orte und Wege des Denkens. Zürich: Amman Verlag.

Jaspers, Karl. 1953 [1949]. The Origin and Goal of History. New Haven: Yale University Press.

Kuchenbuch, David. 20 I I. "Arno Peters die Peterskarte und die Synchronoptische Weltgeschichte", Zeitschrift für Geschichtswissenschaft 59, 824-846.

Maddison, Angus. 2007. Contours of the World Economy I-2030 AD: Essays in Macroeconomic History. Oxford: Oxford University Press.

Manning, Patrick. 2003. Navigating World History: Historians Create a Global Past. New York: Palgrave.

20 I I. "Epistemology", in Bentley, Jerry H., The Oxford Handbook of World History. Oxford: Oxford University Press.

McEvedy, Colin. 20 I I. Cities of the Classical World. An Atlas and Gazetteer of I20 Centres of Ancient Civilization. London: Penguin.

— \& Jones, Richard. 1978. Atlas of World Population History. London: Lane.

Myrdal, Janken. I995. "Bonderesningar och bondekrig", Folkets historia I995(2-3), I $4-66$.

_ 1997. "Mittelalterliche Bauernerhebungen und Bauernkriege in Europa", in Historie und Eigensinn: Festschrift für Jan Peters. Weimar: Verlag Hermann Böhlaus Nachfolger.

— I999. Jordbruket under feodalismen. Stockholm: Natur och Kultur.

— 2003. "Syntesens roll och världshistorien: Samhällelig komplexitet och imperiernas historia", Historisk tidskrift, 259-284.

20 I 2. "Empire: The Comparative Study of Imperialism", in Hornborg, Alf, Clark, Brett \& Hermele, Kenneth (eds.), Ecology and Power: Struggles over Land and Material Resources in the Past, Present, and Future. Oxford: Routledge.

20I4. Agricultural Literature in Eurasia circa 200 BCE-I500 CE, Stockholm Papers in Economic History, No. I 5 (http://swopec.hhs.se/suekhi).

Needham, Joseph. I954. "Introductory Orientations", in Science and Civilisation in China I. Cambridge: Cambridge University Press.

- (ed.). 1954-. Science and Civilisation in China I-. Cambridge: Cambridge University Press.

Neveux, Hugues. 1997. Les révoltes paysannes en Europe: (XIVe-XVIIe siècle). Paris: Albin Michel.

Northrop, Douglas. (ed.). 20 r 2. A Companion to World History. Malden, MA: Wiley Blackwell.

Oles, Douglas Stuart. 20 I I. "Introduction", in McEvedy, Colin, Cities of the Classical World: An Atlas and Gazetteer of 120 Centres of Ancient Civilization. London: Penguin.

Oswalt, Vadim. 201 5. Weltkarten - Weltbilder: Zehn Schlüsseldokumente der Globalgeschichte. Stuttgart: Reclam.

Parker, Geoffrey. 1978. "Introduction”, in Parker, Geoffrey \& Smith, Lesley M. (eds.), The General Crisis of the Seventeenth Century. London: Routledge.

2013. Global Crisis: War, Climate Change and Catastrophe in the Seventeenth Century. New Haven: Yale University Press. 
Peters, Arno. I952. Synchronoptische Weltgeschichte. Munich \& Hamburg: Universum Verlag.

Pinker, Steven. 20 I 2. The Better Angels of Our Nature: A History of Violence and Humanity. London: Penguin.

Pomeranz, Kenneth. 2000. The Great Divergence. China, Europe, and the Making of the Modern World Economy. Princeton: Princeton University Press.

Popper, Karl R. 1965. Conjectures and Refutations: The Growth of Scientific Knowledge. New York \& Evanston: Harper Torchbook.

Rosenberg, Daniel \& Grafton, Anthony. 2010. Cartographies of Time: A History of the Timeline. New York: Princeton Architectural Press.

Schwartzberg, Joseph E. (ed.). 1978. A Historical Atlas of South Asia. Chicago: University of Chicago Press.

Skocpol, Theda. 1984. "Emerging Agendas and Recurrent Strategies in Historical Sociology", in Skocpol, Theda (ed.), Vision and Method in Historical Sociology. Cambridge: Cambridge University Press.

Sorokin, Pitrim. 1937-1941. Social and Cultural Dynamics I-4. London: George Allen \& Unwin.

— 1957. Social and Cultural Dynamics: A Study of Change in Major Systems of Art, Truth, Ethics, Law and Social Relationships. Boston: Porter Sargent Publisher.

Sparks, John B. I990. Histomap of World History. Chicago: Rand McNally.

Taagepera, Rein. 1978. "Size and Duration of Empires: Systematics of Size", Social Science Research 7, 108-1 27.

_ 1997. "Expansion and Contraction Patterns of Large Polities: Context for Russia”, International Studies Quarterly 4I(4), 475-504.

Teeple, John B. 2002. Timelines of World History. London: DK Publishing.

Wickham, Chris. 2005. Framing the Early Middle Ages: Europe and the Mediterranean, 400-800. Oxford: Oxford University Press.

Witke, Anne-Maria, Olshausen, Eckart \& Szydlak, Richard. 2007. Historicher Atlas der antiken Welt (Der neue Pauly: Supplemente 3). Stuttgart: Metzler.

Wittrock, Björn. 2005. "The Meaning of the Axial Age”, in Árnason, Jóhann Páll, Eisenstadt Shmuel Noah \& Wittrock, Björn (eds.), Axial Civilizations and World History. Leiden: Brill.

World History Timeline. 20I 4. Huddersfield: Shoefield and Sims.

Yamasaki, Shigehisa. 1999. Chronological Chart of World Cultural History. Tokyo: Geishinsha.

Yoffee, Norman. 2005. Myths of the Archaic State. Evolution of the Earliest Cities, States, and Civilizations. Cambridge: Cambridge University Press.

Zanden, Jan Luiten van. 2009. The Long Road to the Industrial Revolution: The European Economy in a Global Perspective, I000-1800. Leiden: Brill.

\section{Internet sources}

United States Census Bureau: https://www.census.gov/population/international/data/ worldpop/table_history.php. 